\title{
Energijos vartojimo Lietuvoje ir ES šalyse tendencijos
}

Vaclovas Miškinis,

Arvydas Galinis,

Inga Konstantinavičiūtè,

Vidas Lekavičius

Lietuvos energetikos institutas,

Energetikos kompleksiniu

tyrimu laboratorija,

Breslaujos g. 3,

LT-44403 Kaunas

El.paštas: vaclovas.miskinis@lei.lt
Rengiant Lietuvai reikšmingus energetikos sektoriaus perspektyvinès plètros projektus ir strateginius dokumentus, labai svarbu detaliai analizuoti energijos vartojimo ūkio šakose kaitos tendencijas, įvairiapusiškai pagrịsti racionalius energijos poreikius, kurie sudarytų palankias prielaidas tolesniam šalies ekonomikos augimui. Šio straipsnio tikslas - apibendrinti metodinius energijos balanso rengimo principus, nustatyti energijos vartojimo pokyčius 2000-2012 m. ir ívertinti energijos suvartojimo ūkio šakose ir ekonomikos augimo tarpusavio ryšius, taip pat atlikti energijos vartojimo rodiklių Baltijos šalyse ir pasirinktose ES šalyse lyginamąją analizę.

Raktažodžiai: pirminè energija, galutinè energija, energijos intensyvumas, energijos balansas

\section{IVADAS}

Energetikos sektorius yra neatsiejama modernios visuomenès sudedamoji dalis ir kartu labai sudètinga ūkio šaka, turinti didžiulę ịtaką kiekvienos valstybès ekonomikai, jos struktūrai, ekonomikos augimo tempams, socialinei ir ekonominei gero- vei. Energetikos užduotis - užtikrinti tradicinių iškastinio kuro (naftos, gamtinių dujų, anglių) ir atsinaujinančių energijos išteklių tiekimo kanalų ìvairovę ir patikimumą, gamtinių energijos išteklių transformavimą i elektros energiją ir centralizuotai tiekiamą šilumą ar jų perdirbimą i vartotojams labiau tinkamas kuro rūšis, taip pat 
energijos prieinamumą vartotojams tinkamu lai$\mathrm{ku}$ ir priimtinomis kainomis. Ivairūs energijos ištekliai vartojami gamtinių žaliavų ir kitokių medžiagų gavybai, jų perdirbimui i pardavimui tinkamas medžiagas ar gaminius, panaudojamus tolesnei pramoninei gamybai, įvairių įrenginių ir produktų gamybai, jų transportavimui ir paskirstymui. Daug energijos suvartojama transporto, namų ūkio ir paslaugų sektoriuose.

Rengiant šalies energetikos ir ekonomikos plètros strategijas, planuojant investicijas, pagrindžiant naujų technologijų diegimo tikslingumą, reikia turèti pakankamai informacijos apie įvairių energijos rūšių sąnaudas. Šiam tikslui galima pasitelkti šalies energijos balansus, kuriuose analizuojama ūkio šakose naudojamų energijos išteklių gamyba, eksportas, importas, atsargų pokytis, detalizuojamos įvairių energijos rūšių sąnaudos pagal paskirtị (elektros energijai ir šilumai gaminti, perdirbimui $\mathfrak{i}$ kitas rūšis, neenergetinèms reikmèms) ir pagal vartotojų kategorijas. Pagal tarptautinių organizacijų, rengiančių apibendrintus energijos balansus, metodinius principus ypač didelis dèmesys skiriamas galutinès energijos suvartojimo detalizavimui. Energijos išteklių vartojimo analizè yra labai svarbus etapas kompleksiškai modeliuojant šalies energetikos sektoriaus raidą ilgalaikeje perspektyvoje bei taikant modernius energijos poreikių prognozavimo ir plettros krypčių optimizavimo modelius [1-3].

Detali, ịvairiapusiška, laiku pateikta ir patikima informacija apie ịvairių energijos ištekliu vartojimą yra labai reikšminga energetikos sektoriaus būsenai apibūdinti kiekvienos valstybès ir pasaulio mastu. Patikimi duomenys apie energijos išteklių gamybą, tiekimą, atsargas, importą, eksportą, transformavimą ir galutinị suvartojimą yra pagrindas priimant teisingus sprendimus ir formuojant energetikos politiką. Lietuvoje duomenis apie energijos išteklių suvartojimą visose grandyse, pradedant jų gavyba ar importu ir baigiant suvartojimu galutinių vartotojų irrenginiuose, kaupia, apibendrina ir rengia metinius energijos balansus Statistikos departamentas. Energijos balansai sudaromi remiantis visų nuosavybès formų îmonių, gaminančiu, importuojančių, prekiaujančių energijos ištekliais, juos vartojančių ar transformuojančių, metiniais faktiniais duomenimis, kurie pateikiami nustatytos formos klausimynuose, laikantis bendrų reikalavimų. Taip sudaromos prielaidos parengti nacionalini energijos balansą, iš esmès atitinkantị bendrus metodinius principus, kuriuos taiko tarptautinès statistikos organizacijos $[4,5]$.

Šio straipsnio tikslas - nustatyti energijos vartojimo Lietuvoje pokyčius 2000-2012 m. laikotarpiu ir įvertinti energijos sąnaudų ūkio šakose ir ekonomikos augimo tarpusavio ryšius, taip pat pateikti energijos vartojimą apibūdinančių rodiklių Baltijos šalyse ir pasirinktose ES šalyse lyginamąją analizę.

\section{METODINIAI ANALIZĖS PRINCIPAI}

Energijos suvartojimo kaitos analizè remiasi metinių energijos balansų duomenimis, kuriuos rengia nacionalinès statistikos institucijos. Metinis energijos balansas tarptautineje statistikoje yra itteisintas kaip pagrindinis būdas įvairiapusiškai apibūdinti energetikos sektoriaus būklę. Siekiant kaip galima išsamiau atspindèti kiekvienos kuro ir energijos rūšies tiekimo ir vartojimo kryptis, energijos balanso lentelèse griežtai ir nuosekliai fiksuojami energijos srauto pokyčius atspindintys duomenys, pradedant konkretaus energijos ištekliaus gavyba (gamyba), importu, eksportu, atsargų pokyčiu, suvartojimu tarptautiniam jūriniam bunkeriavimui, jo transformavimu ir baigiant galutiniu suvartojimu vartotojų ịrenginiuose. Šis principas užtikrina, kad bendrosios šalies vidaus energijos sąnaudos ịvertina ne tik tą energijos kiekị, kurị suvartoja galutiniai vartotojai, bet ir neišvengiamus pirminès energijos ištekliu praradimus kuro pakeitimo ir energijos transformavimo sektoriuje, patiriamus gaminant elektros energiją, šilumą, naftos produktus, durpių briketus ir pan. Energijos nuostoliai nustatomi fiksuojant ịvairiuose šio sektoriaus objektuose (elektrinèse, katilinèse, naftos gavybos ir perdirbimo imonèse ir kt.) suvartotą pirminès energijos išteklių ir pagamintų antrinès energijos išteklių kiekį, taip pat ịvertinant kuro ir energijos sąnaudas energetikos įmonių savosioms reikmèms tenkinti.

Siekiant išvengti skirtingo pirminès energijos praradimų energijos transformavimo grandyje vertinimo ịvairiose šalyse, tarptautineje statistikoje laikoma, kad visų branduolinių elektrinių naudingumo koeficientas yra lygus $33 \%$, o 
hidroelektrinių, vèjo ir saulès elektrinių - $100 \%$. Lietuvos energijos balanse prie vietiniu pirminès energijos išteklių priskiriama šiluma, gaunama iš cheminių procesų energijos. Energijos balanse nurodomas toks šios šilumos kiekis, koks realiai sunaudojamas elektrai, karštam vandeniui ar garui gaminti, įmonių technologinėms reikmėms ir pan. Lietuvoje panaudojamas šios energijos kiekis reikšmingas ir pasaulio energijos balanso kontekste - $2011 \mathrm{~m}$. OECD organizacijai priklausančiose šalyse (tarp jų Belgijoje, Korejoje, Naujojoje Zelandijoje, Norvegijoje, Suomijoje, Švedijoje) kartu paèmus, tokios atliekinès šilumos (gautos daugiausiai iš cheminių procesų energijos) panaudota 630 tūkst. tne, o Lietuvoje - 244 tūkst. tne. 2011 m. didžioji dalis $(68,8 \%)$ iš cheminių procesų gautos šilumos Lietuvoje sunaudota tiesiogiai įmonių technologinèms reikmèms, $28,0 \%$ - elektrai gaminti ir 3,2 \% patiekta Kèdainių miesto vartotojams.
Lietuvoje suvartojamų energijos išteklių apimtis, elektros energetikos, centralizuotai tiekiamos šilumos bei naftos perdirbimo sektorių svarbą ir galutinès energijos vartojimo proporcijas korektiškai apibūdina 1 pav., kuriame pateikti pagrindinių energijos išteklių tiekimo, transformavimo ir galutinio suvartojimo ūkio šakose kiekiai. Ši diagrama parengta remiantis $2012 \mathrm{~m}$. šalies energijos balansu [6]. Visų energijos išteklių kiekiai kiekvienoje srauto grandyje iš natūrinių vienetų perskaičiuoti sutartiniais vienetais - tūkstančiais tonų naftos ekvivalento (tne). Be to, kiekvienos kuro ir energijos rūšies srauto plotis šioje diagramoje iliustruoja tos kuro ar energijos rūšies energetinę vertę bendrame energijos balanse, išskyrus srautą, kuris apibūdina Lietuvoje pagamintų ir ị kitas šalis eksportuotų naftos produktų kieki. Naftos perdirbimo gamykla buvo statoma dideliam buvusios Sovietų Sajungos regionui aptarnauti, todèl perdirbamos naftos ir eksportuoja-

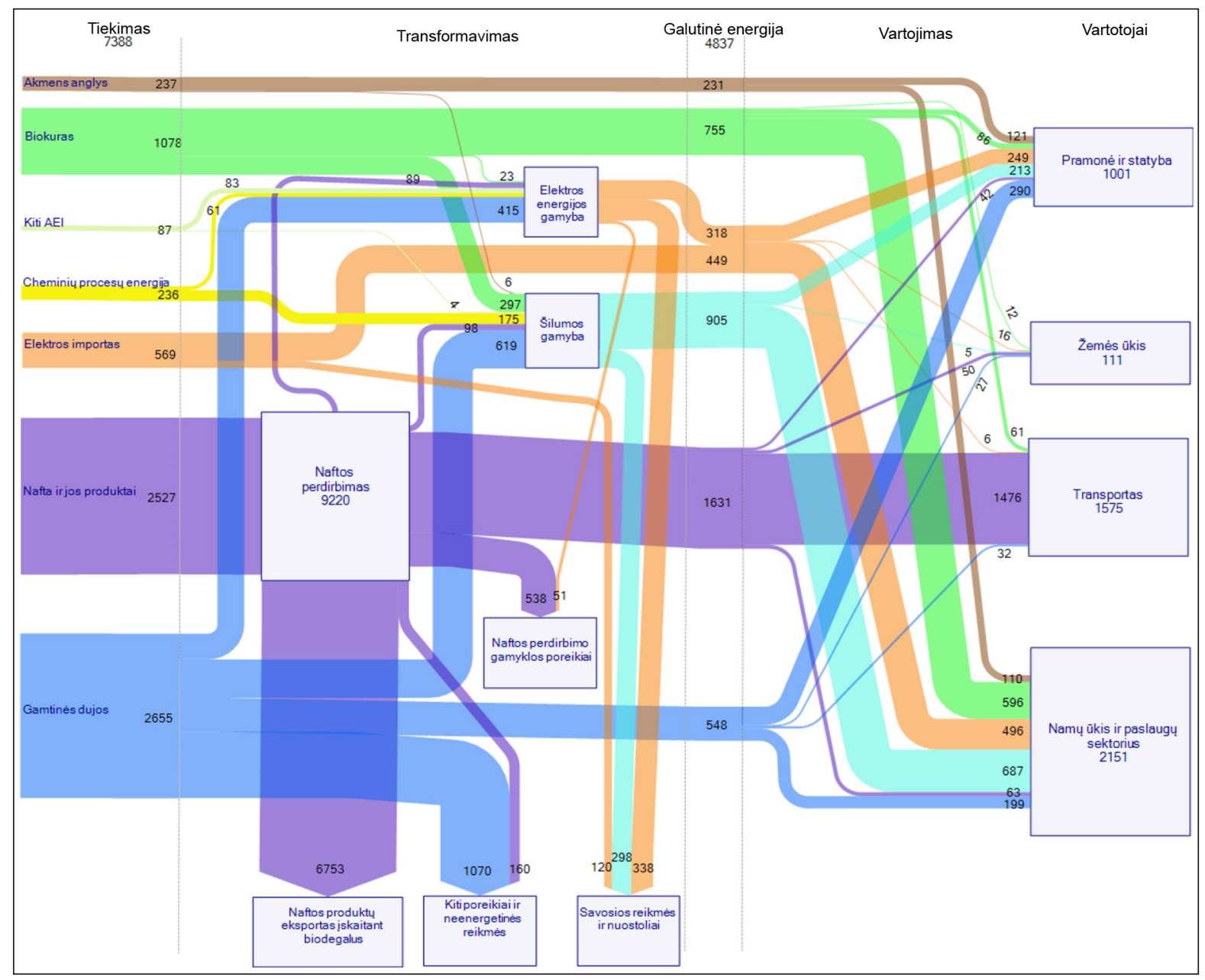

1 pav. Pagrindinių Lietuvos kuro ir energijos srautų diagrama 2012 m., tūkst. tne 
mų naftos produktų kiekis, beveik keturis kartus viršijantis šalies vidaus poreikius, vaizduojamas stambesniu masteliu.

Šioje diagramoje išskirti trys energijos srautų grandinès lygiai:

1) pirminès energijos tiekimo;

2) gamtinių energijos išteklių transformavimo;

3) galutinès energijos suvartojimo.

Pirmines energijos tiekimas - tai visoms šalies reikmėms suvartota energija, esanti šalies viduje išgautuose ir importuojamuose gamtos ištekliuose:

- cheminè energija, slypinti organiniame kure (naftoje, gamtinèse dujose, akmens anglyse, durpese ir pan.);

- atsinaujinančių energijos išteklių energija (vandens rezervuarų potencinè energija, vejjo energija, biologinès masès (medienos ir biologiškai skaidžios biologinès kilmès produktų, žemès ūkio atliekų, ịskaitant augalinès ir gyvulinès kilmès medžiagas, pramonès ir buitinių atliekų) energija, geoterminè energija, saulès radiacijos energija ir kt.). Šių išteklių kiekis dèl natūraliai gamtoje vykstančių procesų ir žmonių veiklos nuolat atsinaujina;

- branduolinių reakcijų išskiriama energija ir kt. Kaip matyti 1 pav., viena pirminès energijos išteklių dalis tiesiogiai tiekiama galutiniams vartotojams, kita dalis suvartojama gaminant elektrą ir centralizuotą šilumą bei perdirbama naftos produktų gamykloje. Atskiruose blokuose identifikuoti energijos transformavimo sektoriuje patiriami nuostoliai ir energetikos imonių savosios reikmès, naftos perdirbimo gamyklos poreikiai, neenergetinèms reikmėms suvartoti energijos ištekliai. $2012 \mathrm{~m}$. Lietuvoje suvartota 7388,4 tūkst. tne pirminès energijos išteklių, o galutiniams vartotojams patiekta 4837,1 tūkst. tne.

Galutine energija vadinama ta pirminių gamtinių išteklių (akmens anglių, gamtinių dujų, naftos ir kt.) ir antrinių energijos išteklių (elektros energijos, naftos produktų, centralizuotai tiekiamos šilumos ir kt.) dalis, kurią tiesiogiai savo įrenginiuose suvartoja galutiniai vartotojai (pramoné, žemés ūkis, transporto ir prekybos bei paslaugų sektoriaus i̇monès, individualūs vartotojai ir pan.). Galutine energija suvartojama tam tikrai produkcijai gaminti, krovinių ir keleivių pervežimui, reikalinga bet kuriai kitai ūkinei veiklai vykdyti ar paslaugoms teikti bei tinkamoms gyvenimo sąlygoms užtikrinti. Todèl Lietuvos energijos balanse (taip pat ir Eurostato duomenų bazeje [7]) energijos ištekliai, suvartojami neenergetinėms reikmėms, t. y. kaip žaliava arba medžiagos, sunaudojamos ịvairiose veiklose, pateikiami atskira eilute, bet nesumuojami prie galutinès energijos. Tarptautinès energetikos agentūros duomenų bazèje ir ịvairiuose statistikos leidiniuose neenergetinès reikmès yra "bendrojo galutinio vartojimo" sudedamoji dalis. Iki $2004 \mathrm{~m}$. paskelbtuose statistikos leidiniuose šios reikmès buvo priskiriamos prie galutinès energijos sąnaudų konkrečiose ūkio šakose $[8,9]$. Latvijos statistikos duomenų bazejje iki šiol neenergetinèms reikmèms sunaudojami naftos produktai (pvz., bitumas, tepalai, parafinas) priskiriami prie ūkio šaku galutinès energijos sąnaudų [10]. Todèl, siekiant korektiškai palyginti lyginamuosius energijos vartojimo rodiklius, būtina labai kruopščiai revizuoti ịvairiose statistikos duomenų bazèse ir statistikos leidiniuose pateiktus duomenis.

Dinaminių pirminès energijos, galutinès energijos ar atskirų kuro ir energijos rūšių suvartojimo atskiruose sektoriuose eilučiu parengimas, taikant tuos pačius metodinius principus, yra būtina sąlyga korektiškai energijos vartojimo ìvairiose šalyse lyginamajai analizei. Kita vertus, energijos suvartojimo tendencijoms atskirose šalyse didelę ịtaką turi makroekonominių rodiklių (BVP augimo, ūkio šakų struktūros ir pan.) kitimas, kuro ir energijos kainų didejimas, skirtinga vartotojų reakcija i̇ pajamų ir energijos kainų augimą, labai skirtingos galimybès didinti energijos vartojimo efektyvumą ir kiti veiksniai. Tokią analizę komplikuoja tai, kad ịvairiuose leidiniuose ir duomenų bazèse skelbiami makroekonominiai duomenys yra nuolat atnaujinami. Todèl šiame straipsnyje pagrindinis dèmesys skiriamas išryškinti energijos vartojimo tendencijas Lietuvoje, lyginamajai analizei pasitelkiant Latvijos ir Estijos statistikos departamentų duomenų bazese pateiktus statistinius duomenis, taip pat pasinaudojant naujaisiais apibendrintais duomenimis, paskelbtais Eurostato duomenų bazejje [7] ir Tarptautinès energetikos agentūros statistikos leidiniuose $[11,12]$. 


\section{ENERGIJOS VARTOJIMO TENDENCIJOS}

Galutinès energijos sąnaudų kaitos tendencijos Modeliuojant bet kurios šalies energetikos raidos kryptis, visu pirma atliekama galutinès energijos sąnaudų, paprastai siejamų su ūkio šakų ekonomine veikla, kaitos tendenciju analizè. Spartaus ekonomikos augimo laikotarpiu 2000-2008 m. energijos sąnaudos didejjo visose Lietuvos ūkio šakose, ypač apdirbamosios pramonès šakų įmonèse, tačiau lètesniais tempais nei augo šalies BVP. Itin sparčiai augo energijos sąnaudos transporte - vidutiniškai net 7,2 \% per metus, gerokai lèčiau statybos sektoriuje $-4,6 \%$, paslaugų sektoriuje $-3,2 \%$, pramonèje $-2,3 \%$, žemès ūkyje - $2,2 \%$ ir namų ūkio sektoriuje - 1,6\%. Suminès galutinès energijos sąnaudos Lietuvos ūkio šakose 2000-2008 m. augo vidutiniškai $3,8 \%$ per metus, o ekonomikos nuosmukio metais sumažèjo 9,4 \%. 2009 m. galutinès energijos sąnaudos statybos sektoriuje sumažèjo net $35,0 \%$, transporte - $18,5 \%$, pramonèje $-11,9 \%$, žemès ùkyje - 10,8\%. Paslaugų sektoriuje galutinès energijos $2009 \mathrm{~m}$. suvartota tik 2,0 \% mažiau. Skirtingai nei kitose ūkio šakose, namų ūkiuose, kur didžioji dalis energijos sunaudojama patalpoms šildyti, dèl žemesnių temperatūru šildymo sezono metu 2009 m. energijos suvartota $1,1 \%$ daugiau nei $2008 \mathrm{~m}$.

Atsigaunant ekonomikai, 2009-2012 m. pramoneje energijos sąnaudos augo vidutiniškai $7,1 \%$ per metus, transporte $-2,1 \%$, o suminès galutinès energijos sąnaudos augo $1,7 \%$ per metus. Remiantis Lietuvos statistikos departamento duomenimis [13], šiuo laikotarpiu nesunku ižvelgti su ekonomikos augimu susijusią galutinès energijos sąnaudų augimo tendenciją (2 pav.). Didžiausią įtaką galutinès energijos sąnaudų augimui ateityje turi ekonominès veiklos plètra pramonès ir transporto sektoriuose ir, iš kitos pusès, energijos vartojimo efektyvumo didinimas, kuri galima pasiekti visose ūkio šakose igyvendinant energiją taupančias priemones, ypač atnaujinant pastatus ir jų vidaus šildymo sistemas namų ūkio ir paslaugų sektoriuose.

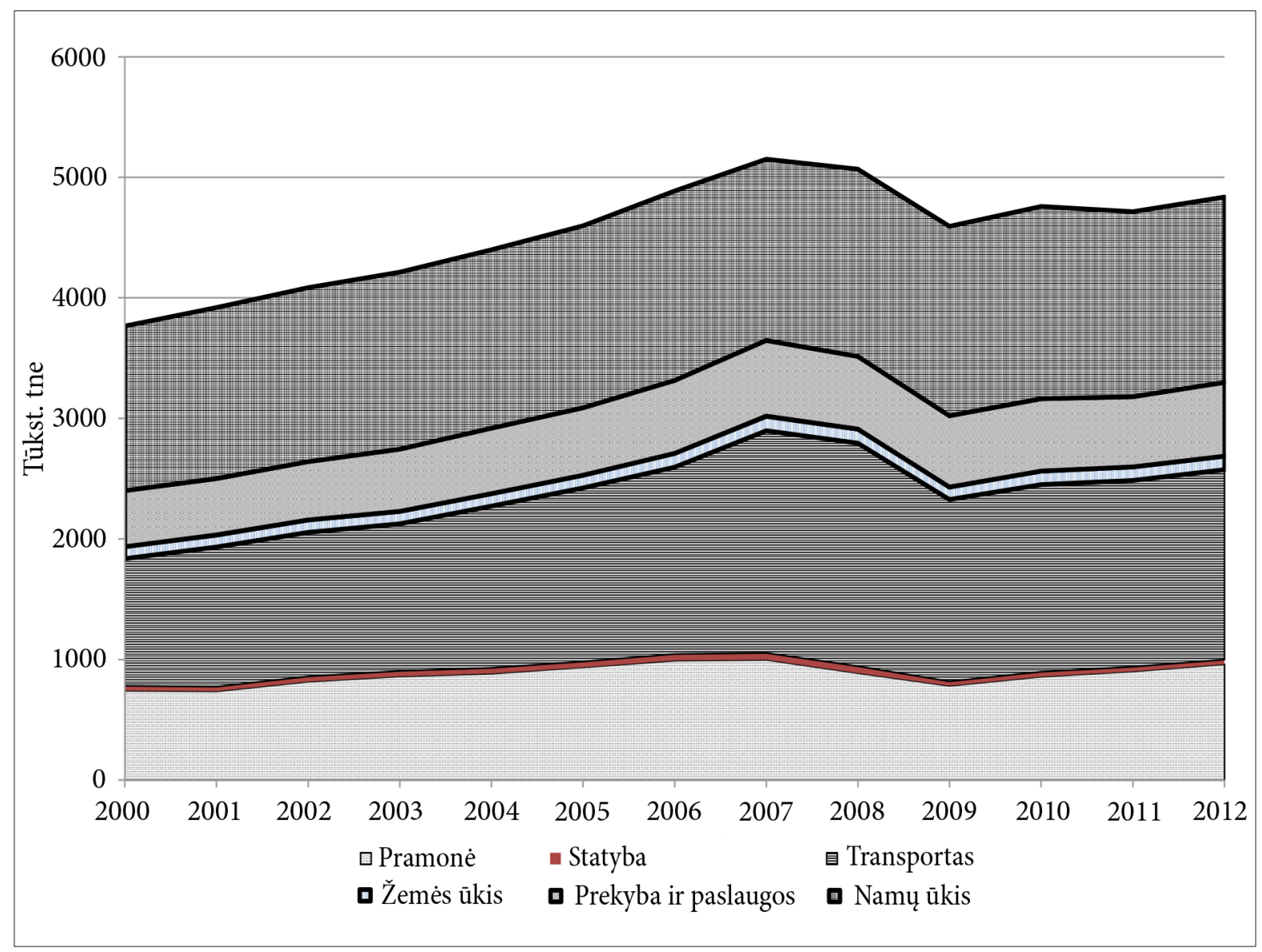

2 pav. Šalies galutinės energijos sąnaudų kaita 


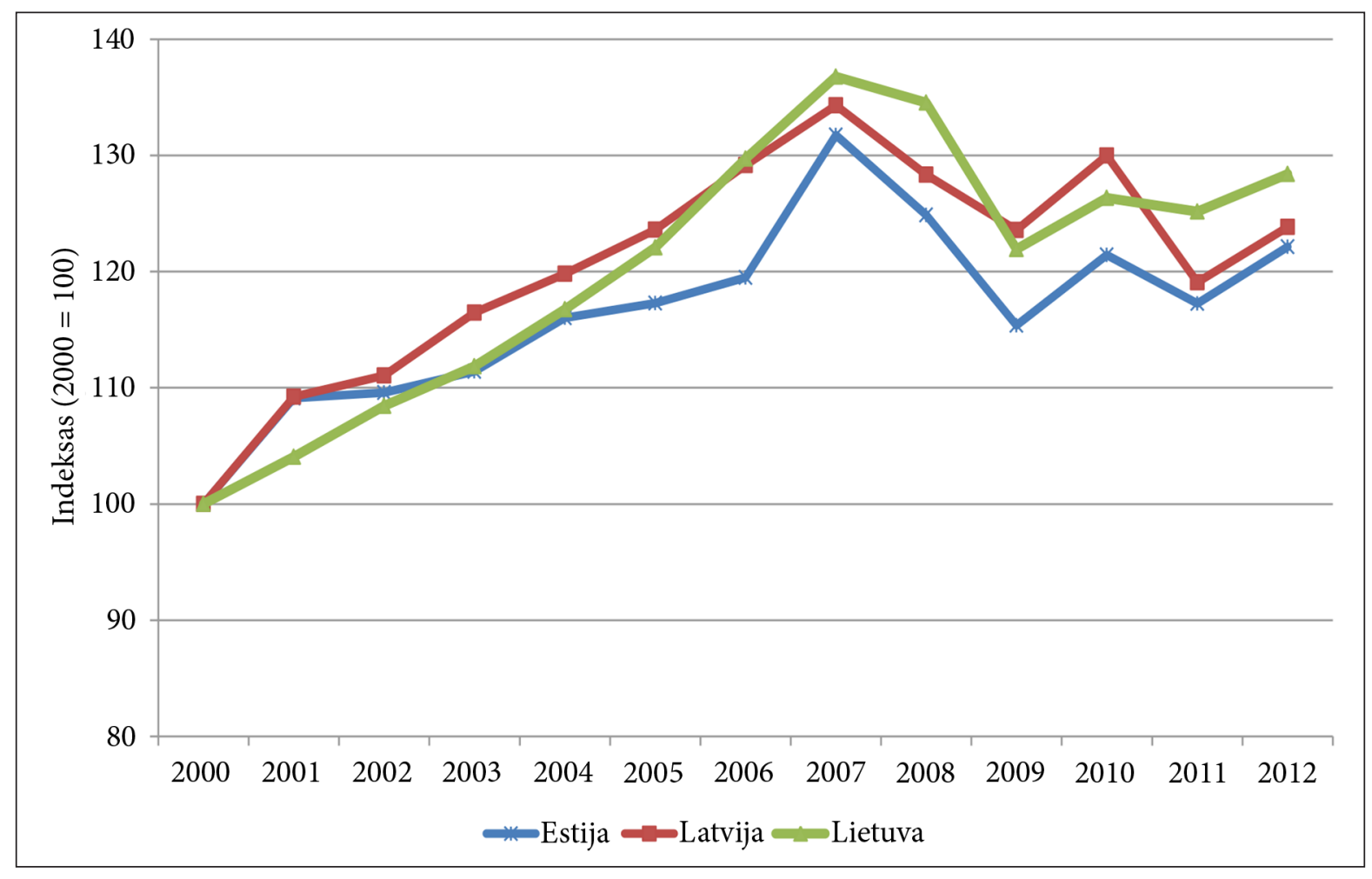

3 pav. Galutinės energijos suvartojimo kaitos indeksas Baltijos šalyse

Nežiūrint 2009 m. akivaizdžiai matomos ekonomikos nuosmukio itakos, galutinès energijos suvartojimas 2000-2012 m. augo vidutiniškai 2,1 \% per metus. Tik statybos sektoriuje $2012 \mathrm{~m}$. galutinès energijos suvartota $2,2 \%$ mažiau nei $2000 \mathrm{~m}$. Visose kitose šalies ūkio šakose energijos suvartojimas šiuo laikotarpiu padidejo: transporte $-49,1 \%$ (kuro suvartojimas šiame sektoriuje augo vidutiniškai 3,4 \% per metus), paslaugų sektoriuje $-32,0 \%$, pramonèje $-29,6 \%$, žemès ūkyje $-12,7 \%$ ir namų ùkio sektoriuje - 12,6\%.

Atlikta analizè patvirtino glaudžius ekonomikos augimo ir ūkio šakose suvartojamos galutinès energijos ryšius ne tik Lietuvoje, bet ir kitose Baltijos šalyse. Palyginti nedidelius galutinès energijos sąnaudų augimo nukrypimus nuo bendros jų augimo tendencijos lèmé daugelis veiksnių: BVP augimo Baltijos šalyse nagrinèjamuoju laikotarpiu tempų skirtumai, skirtingas ekonomikos nuosmukio gylis, nevienoda galutinių vartotojų reakcija i pajamų bei kainų kaitą ir kt. Nepaisant šių skirtumų, bendras galutinès energijos augimo indeksas 2000-2012 m. laikotarpiu mažai skiriasi. Remiantis naujausia prieinama informacija $[10,13,14]$, šis indeksas Estijoje buvo lygus 22,1\%, Latvijoje - 23,9 \%,
Lietuvoje - 28,4 \% (3 pav.). Galutinès energijos ir BVP procentinių pokyčių santykị apibūdinantys elastingumo koeficientai, kurie buvo nustatyti naudojantis Baltijos šalių duomenų bazèse pateiktais duomenimis, skiriasi dar mažiau - esant prielaidai, kad visų kitų veiksnių įtaka tokia pat, Estijoje BVP padidejus $1 \%$, galutinès energijos sąnaudos augo 0,42\%, Latvijoje - 0,46\%, Lietuvoje $-0,47 \%$.

Remiantis Eurostato duomenų bazèje esančia informacija [7], iki ekonomikos krizès galutinès energijos sąnaudos augo visose ES šalyse, išskyrus Jungtinę Karalystę ir Švediją, kur 2008 m. galutinès energijos sąnaudos buvo atitinkamai 5 ir $7 \%$ mažesnès nei 2000 m. Ekonomikos krizès padariniai naujosiose ES šalyse narèse buvo skirtingi. Čekijoje, Slovakijoje ir Vengrijoje daugiausiai dèl ženklaus pramonès nuosmukio galutinès energijos išteklių $2012 \mathrm{~m}$. suvartota mažiau nei $2000 \mathrm{~m}$. Tačiau suminès galutinès energijos sąnaudos naujosiose ES šalyse narèse 2000-2012 m. augo vidutiniškai $0,44 \%$ per metus. Apibendrinti duomenys, pateikti 1 lentelèje, rodo, kad sparčiausiai galutinès energijos sąnaudos augo Baltijos šalyse - Estijoje 1,4 \%, Latvijoje 1,9 \%, Lietuvoje $2,1 \%$ per metus. Išsivysčiusiose ES-15 šalyse 
1 lentelè. Galutinės energijos sąnaudų augimo indeksas ir tempai ES šalyse

\begin{tabular}{ccccccccccc|c|c}
\hline & $\mathbf{2 0 0 0}$ & $\mathbf{2 0 0 5}$ & $\mathbf{2 0 0 6}$ & $\mathbf{2 0 0 7}$ & $\mathbf{2 0 0 8}$ & $\mathbf{2 0 0 9}$ & $\mathbf{2 0 1 0}$ & $\mathbf{2 0 1 1}$ & $\mathbf{2 0 1 2}$ & $\begin{array}{c}\text { Augimo tempai } \\
\mathbf{2 0 0 0 - 2 0 1 2} \mathbf{~ m . ,} \\
\mathbf{\%}\end{array}$ \\
\hline Estija & 100 & 118,3 & 118,4 & 127,5 & 126,0 & 113,7 & 119,5 & 116,6 & 118,0 & 1,39 \\
\hline Latvija & 100 & 124,6 & 130,0 & 135,0 & 128,8 & 125,3 & 132,0 & 120,0 & 124,9 & 1,87 \\
\hline Lietuva & 100 & 122,1 & 129,7 & 136,7 & 134,6 & 121,9 & 126,2 & 125,1 & 128,3 & 2,10 \\
\hline Bulgarija & 100 & 111,5 & 115,3 & 113,6 & 109,6 & 94,4 & 97,1 & 101,7 & 101,5 & 0,12 \\
\hline Čekija & 100 & 105,0 & 106,5 & 104,7 & 103,4 & 98,5 & 102,5 & 99,0 & 97,1 & $-0,25$ \\
\hline Lenkija & 100 & 104,6 & 109,3 & 110,9 & 111,6 & 109,7 & 119,0 & 114,6 & 114,2 & 1,11 \\
\hline Slovakija & 100 & 105,3 & 103,6 & 101,8 & 104,6 & 96,8 & 105,2 & 98,1 & 94,2 & $-0,49$ \\
\hline Slovenija & 100 & 109,9 & 111,0 & 109,5 & 117,8 & 106,4 & 110,5 & 111,4 & 108,9 & 0,71 \\
\hline ES-13 & 100 & 108,2 & 110,5 & 109,8 & 110,5 & 104,6 & 110,0 & 107,2 & 105,4 & 0,44 \\
\hline Austrija & 100 & 119,0 & 117,8 & 116,8 & 117,9 & 112,0 & 119,9 & 116,1 & 115,5 & 1,21 \\
\hline Danija & 100 & 106,9 & 108,1 & 108,5 & 107,1 & 100,0 & 104,7 & 99,7 & 97,3 & $-0,22$ \\
\hline Prancūzija & 100 & 105,1 & 104,3 & 102,2 & 103,4 & 98,9 & 102,3 & 95,1 & 97,3 & $-0,22$ \\
\hline Suomija & 100 & 103,3 & 108,7 & 108,1 & 105,3 & 97,8 & 107,5 & 102,5 & 103,0 & 0,25 \\
\hline Vokietija & 100 & 99,3 & 101,6 & 95,6 & 99,0 & 93,6 & 100,2 & 95,1 & 96,9 & $-0,27$ \\
\hline ES-15 & 100 & 104,7 & 104,5 & 102,5 & 102,9 & 97,0 & 101,4 & 96,6 & 96,5 & $-0,30$ \\
\hline ES-28 & 100 & 105,2 & 105,3 & 103,6 & 104,0 & 98,0 & 102,6 & 98,1 & 97,8 & $-0,19$ \\
\hline
\end{tabular}

2 lentelè. Galutinės elektros energijos sąnaudų augimo indeksas ir tempai ES šalyse

\begin{tabular}{cccccccccc|c|c|c|c}
\hline & $\mathbf{2 0 0 0}$ & $\mathbf{2 0 0 5}$ & $\mathbf{2 0 0 6}$ & $\mathbf{2 0 0 7}$ & $\mathbf{2 0 0 8}$ & $\mathbf{2 0 0 9}$ & $\mathbf{2 0 1 0}$ & $\mathbf{2 0 1 1}$ & $\mathbf{2 0 1 2}$ & $\begin{array}{c}\text { Augimo tempai } \\
\mathbf{2 0 0 0 - 2 0 1 2} \mathbf{~ m . ,} \\
\mathbf{\%}\end{array}$ \\
\hline Estija & 100 & 121,0 & 130,1 & 136,2 & 140,4 & 133,3 & 138,5 & 132,8 & 139,9 & 2,84 \\
\hline Latvija & 100 & 127,9 & 137,2 & 147,5 & 148,0 & 136,3 & 138,8 & 138,3 & 152,9 & 3,60 \\
\hline Lietuva & 100 & 128,7 & 136,0 & 142,9 & 145,9 & 135,0 & 134,4 & 138,4 & 143,9 & 3,08 \\
\hline Bulgarija & 100 & 106,1 & 110,9 & 112,2 & 118,2 & 110,7 & 111,8 & 117,2 & 114,8 & 1,16 \\
\hline Čekija & 100 & 112,0 & 115,5 & 115,9 & 117,5 & 111,2 & 115,8 & 114,9 & 114,7 & 1,15 \\
\hline Lenkija & 100 & 106,9 & 112,6 & 116,1 & 119,2 & 114,3 & 120,7 & 123,6 & 124,3 & 1,83 \\
\hline Slovakija & 100 & 103,8 & 107,4 & 111,6 & 112,5 & 104,9 & 109,6 & 112,7 & 108,7 & 0,70 \\
\hline Slovenija & 100 & 121,1 & 125,1 & 126,0 & 121,7 & 107,3 & 113,7 & 119,8 & 119,2 & 1,48 \\
\hline ES-13 & 100 & 111,0 & 116,0 & 118,4 & 121,0 & 114,1 & 119,5 & 121,7 & 121,0 & 1,60 \\
\hline Austrija & 100 & 113,1 & 118,2 & 120,3 & 119,0 & 115,5 & 120,8 & 120,7 & 122,2 & 1,69 \\
\hline Danija & 100 & 103,1 & 104,1 & 103,1 & 102,0 & 96,9 & 99,7 & 98,4 & 96,8 & $-0,27$ \\
\hline Prancūzija & 100 & 109,8 & 110,9 & 110,7 & 112,4 & 108,6 & 115,4 & 108,5 & 112,8 & 1,01 \\
\hline Suomija & 100 & 106,7 & 113,7 & 113,7 & 109,1 & 101,9 & 110,3 & 105,8 & 106,7 & 0,54 \\
\hline Vokietija & 100 & 108,0 & 109,2 & 109,5 & 109,1 & 102,9 & 110,1 & 108,7 & 108,8 & 0,70 \\
\hline ES-15 & 100 & 109,9 & 111,5 & 112,0 & 112,2 & 106,4 & 111,4 & 108,7 & 109,2 & 0,73 \\
\hline ES-28 & 100 & 111,0 & 112,1 & 112,7 & 113,2 & 107,3 & 112,3 & 110,2 & 110,6 & 0,84 \\
\hline
\end{tabular}

galutinès energijos išteklių $2012 \mathrm{~m}$. suvartota 3,5\% mažiau nei 2000 m. Tačiau Austrijoje, Ispanijoje, Nyderlanduose ir Suomijoje galutinès energijos išteklių sąnaudos $2012 \mathrm{~m}$. nežiūrint ekonomikos nuosmukio, palyginti su $2000 \mathrm{~m}$. lygiu, padidejo.

Dar sparčiau ekonomikos augimo laikotarpiu ES-28 šalyse augo galutinès elektros energijos sąnaudos - vidutiniškai 1,6 \% per metus. Tai iliustruoja 2 lenteleje pateikti duomenys, parengti remiantis Eurostato duomenų bazès informacija [7]. Sparčiausiai galutinès elektros energijos sąnaudos augo Baltijos šalyse - Latvijoje 5,0 \%, Lietuvoje 4,8 \%, Estijoje 4,3 \% per metus. Sparčiai galutinès elektros energijos sąnaudos augo ir kitose ES šalyse - Kroatijoje 4,0 \%, Ispanijoje $3,9 \%$, Airijoje 3,5 \%, Portugalijoje 2,9 \%, Slovè- 
nijoje 2,5 \%, Austrijoje ir Lenkijoje 2,2 \%, Italijoje 1,6\%. Tik Švedijoje galutinès elektros energijos sąnaudos šiuo laikotarpiu mažai keitėsi. Ekonomikos nuosmukis iš esmès turejo įtakos visoms ES šalims, tačiau daugumoje šalių $2012 \mathrm{~m}$. galutinès elektros energijos sąnaudos buvo didesnès nei 2000 m., tarp jų - Latvijoje 52,9 \%, Lietuvoje 43,9 \%, Estijoje 39,9 \%, Lenkijoje 24,3 \%, Austrijoje 22,2\%, Slovenijoje 19,2\%. $2012 \mathrm{~m}$. tik trijose ES šalyse - Danijoje, Švedijoje ir Jungtinejje Karalystėje - galutiniai vartotojai suvartojo mažiau elektros energijos nei $2000 \mathrm{~m}$.

\section{Pirminès energijos sąnaudų kaita}

Pirminès energijos išteklių poreikius bet kurioje šalyje didžiąa dalimi lemia galutiniai energijos vartotojai - apdirbamosios pramonès struktūra ir gaminamos produkcijos apimtys, pervežamų krovinių ir keleivių pasiskirstymas pagal transporto rūšis, gyventojų mobilumas, paslaugų ir aptarnavimo sektoriaus teikiamų paslaugų apimtys, gyvenimo kokybe ir komforto lygis namų ūkio sektoriuje ir kt. Faktiniai statistiniai duomenys [13] patvirtina, kad tuos pačius galutinès energijos poreikius galima užtikrinti suvartojant gerokai daugiau arba mažiau pirminès energijos išteklių. Kaip matyti iš 4 pav. išryškintų bendrus šalies pirminès energijos poreikius apsprendžiančių pagrindinių komponenčių, pirminès energijos sąnaudų kitimui didelę ịtaką turi:

1) energijos sąnaudos energetikos sektoriuje, kurių apimtis priklauso nuo naftos perdirbimo gamykloje perdirbamos žaliavos ir pagamintų naftos produktų kiekio bei gamyklos įrenginių panaudojimo efektyvumo;

2) elektros energijos ir centralizuotai tiekiamos šilumos transportavimo ir paskirstymo nuostoliai (2000-2012 m. sumažèjo 1,8 karto);

3) neenergetinèms reikmėms sunaudojamų energijos išteklių kiekis (2012 m. suvartota 1,8 karto daugiau nei $2000 \mathrm{~m}$.), kurio svyravimas yra susijęs su eksportuojamų gaminių galimybe konkuruoti pasaulio rinkose;

4) nuostoliai energijos transformavimo sektoriuje, kuriuos lemia elektros energijos gamybos, jos eksporto ir importo santykis bei centralizuotai tiekiamos šilumos gamybos apimčių svyravimai.

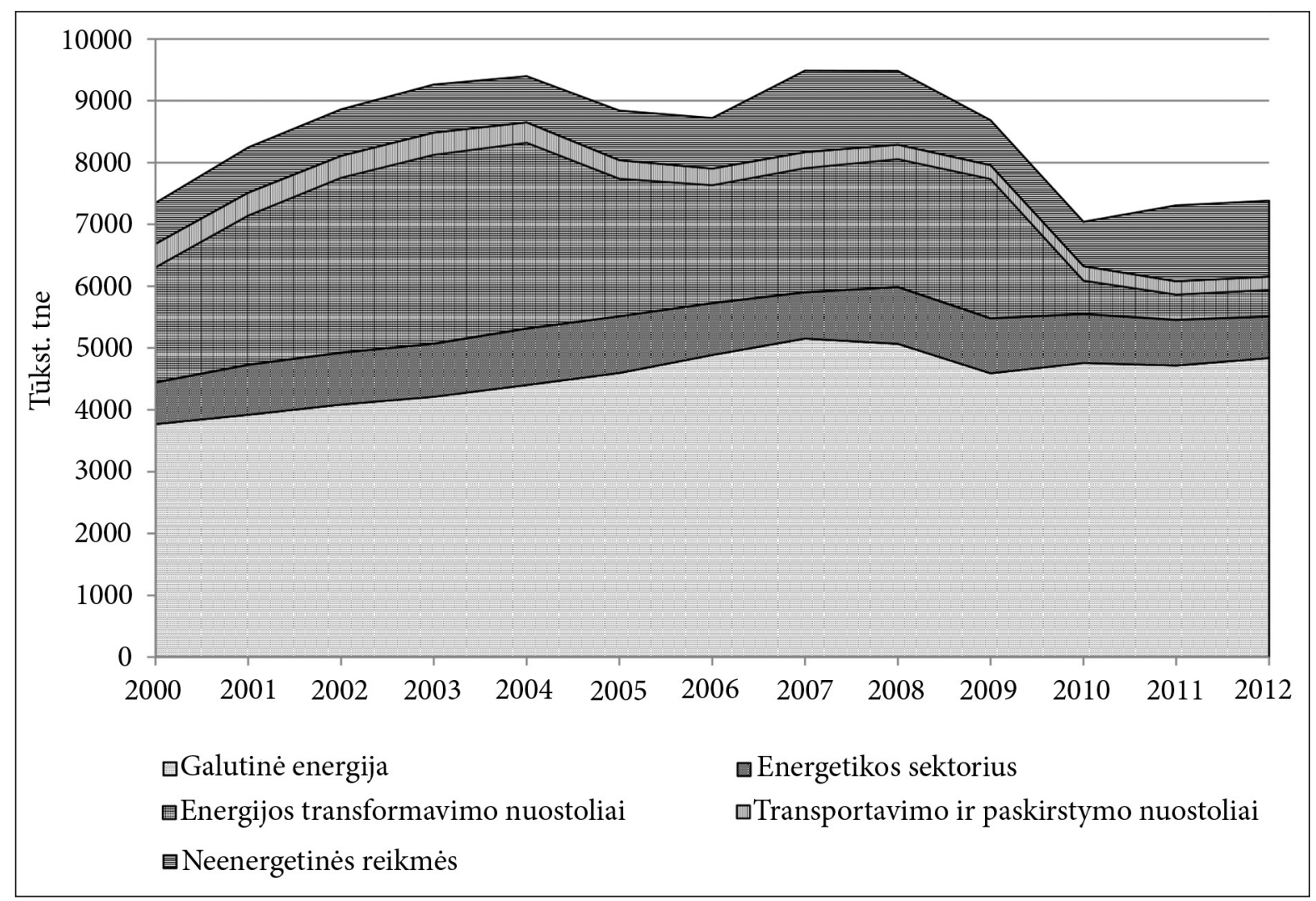

4 pav. Lietuvos pirminès energijos sąnaudų kaita 
2009 m. uždarius Ignalinos AE ir didžiąją dali elektros energijos importuojant iš kaimyninių šalių, ši komponentè akivaizdžiai sumažèjo - $2012 \mathrm{~m}$. energijos transformavimo nuostoliai buvo 4,4 karto mažesni nei $2000 \mathrm{~m}$. ir net 7,2 karto mažesni nei $2003 \mathrm{~m}$.

2000-2008 m. laikotarpiu, augant galutinès energijos išteklių suvartojimui ūkio šakose, buvo izžvelgiama pirminès energijos sąnaudų augimo tendencija, kurios kitimui atskirais metais didelę itaką turèjo elektros energijos eksportui sunaudojamo branduolinio kuro kiekio svyravimai - padidejus (sumažèjus) elektros eksportui, atitinkamai padidedavo (sumažèdavo) ir suminès pirminès energijos sąnaudos. Labai sumažejus šalyje pagamintos elektros energijos apimtims, tuo pačiu ir nuostoliams energijos transformavimo sektoriuje, pirminès energijos per pastaruosius trejus metus buvo suvartojama gerokai mažiau, tačiau jau ryškejja nuosaikaus jos poreikių augimo tendencija.

2000-2008 m. ekonomika Baltijos šalyse augo labai sparčiai - Estijoje vidutiniškai 6,1 \%, Latvijoje 7,3 \%, Lietuvoje 7,4 \% per metus, kai ES-28 šalyse sukuriamas BVP tuo pat metu augo vidutiniškai 2,0 \% per metus. Ekonomikos augimas lèmé aiškią pirminès energijos suvartojimo augimo tendenciją Estijoje, Latvijoje ir Lietuvoje, bet nuosaikų suminių poreikių augimą ES-28 šalyse [7]. Kaip matyti 5 pav., pirminès energijos augimo tempai Baltijos šalyse buvo panašūs. $2008 \mathrm{~m}$. Lietuvoje pirminès energijos suvartota $31,3 \%$, Latvijoje 21,5 \%, Estijoje 19,5 \%, naujosiose ES šalyse 10,3 \% daugiau nei $2000 \mathrm{~m}$. Lietuvoje ženklų pirminès energijos sąnaudų augimą šiuo laikotarpiu lèmé 1,8 karto padidejjusios sąnaudos neenergetinèms reikmèms ir iš dalies padidèjęs elektros energijos eksportas. Net ir nuosaikus ekonomikos augimas šiuo laikotarpiu lèmè bendrą ES-28 šalyse suvartojamų pirminès energijos išteklių padidèjimą 4,2 \%. 2009 m. globali ekonomikos krizè lèmè pirminès energijos sąnaudu sumažèjimą: Estijoje net 10,0 \%, Lietuvoje 8,7 \%, Latvijoje 3,9 \%, ES-28 vidutiniškai 5,8 \%, ES-13 šalyse 6,7 \%. 2010 m., atsigaunant ekonomikai, daugumoje šalių energijos suvartojimas padidèjo - ES-28 šalyse vidutiniškai 3,8 \%, Estijoje $14,9 \%$, Latvijoje 5,7 \%, o Lietuvoje (dèl Ignalinos AE uždarymo) sumažèjo net $20 \%$.

Energijos vartojimo efektyvumo direktyvoje nustatytas ambicingas ES siekis iki $2020 \mathrm{~m}$. sumažinti pirminès energijos sąnaudas absoliučiu

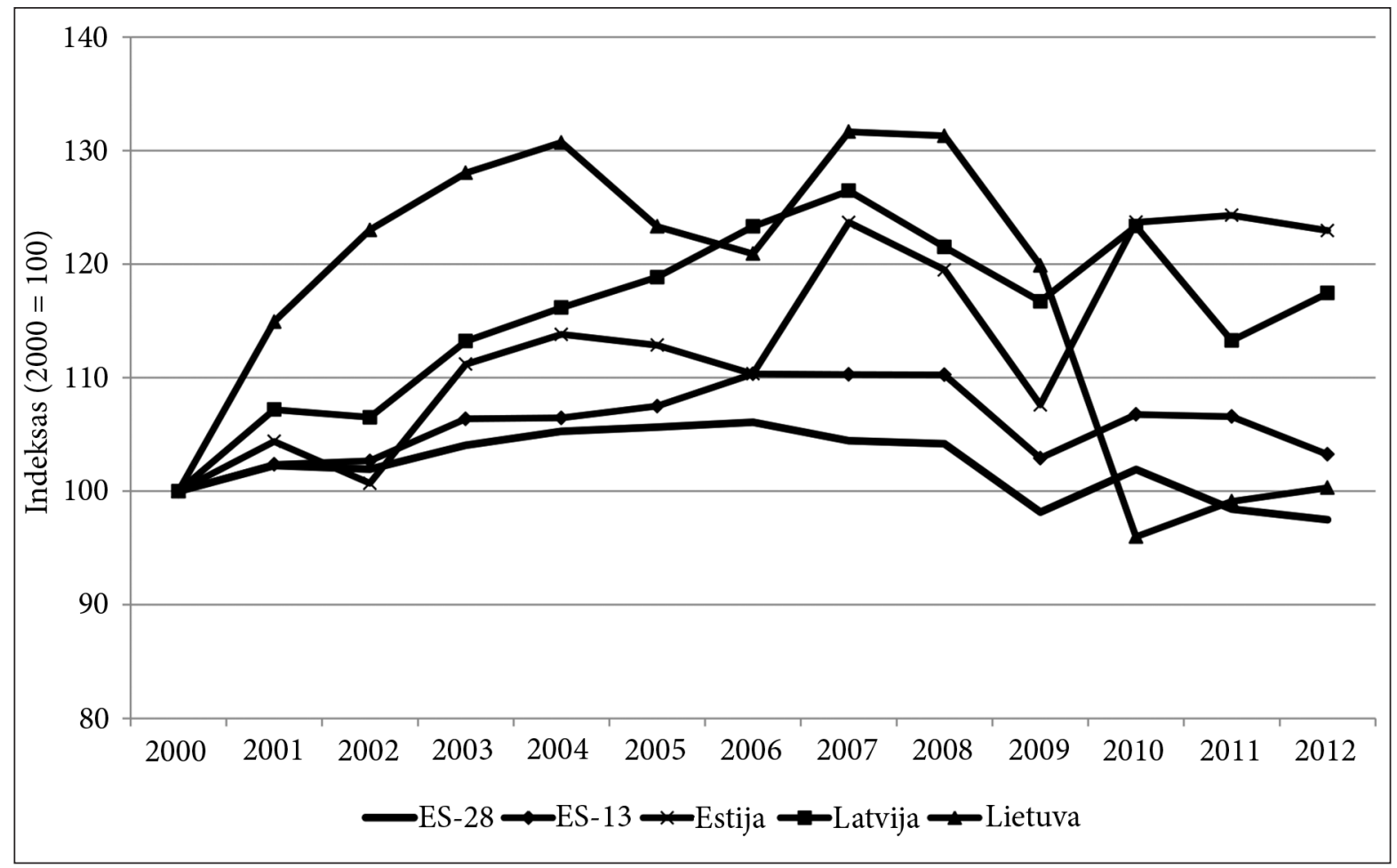

5 pav. Pirminės energijos suvartojimo kaitos indeksas 
dydžiu $20 \%$, palyginti su 2007 m. prognoze [15]. Lietuva, siekdama pagal šios direktyvos reikalavimus nustatyti savo nacionalinị tikslą, privalo remtis kompleksine energetikos sektoriaus raidos ilgalaikèje perspektyvoje analize ir įvertinti ne tik realias galimybes reikšmingai padidinti energijos vartojimo efektyvumą, bet ir energetinio saugumo ar kitais motyvais apibrèžtas elektros energijos gamybos šalies elektrinèse apimtis bei atitinkamą pirminès energijos poreikio augimą.

\section{ENERGIJOS VARTOJIMO LYGINAMIEJI RODIKLIAI}

\section{Energijos vartojimo intensyvumas}

Lietuva iš sovietinès praeities paveldejo galingą energetikos sektorių, skirtą ne tik šalies vidaus reikmèms tenkinti, bet ir elektros energijos bei naftos produktų eksportui i̇ platų buvusios Sovietų Sąjungos regioną. Šalies ūkio, ypač pramonès ir žemès ùkio, struktūra buvo energijai imli ir didele dalimi taip pat orientuota eksportui į Rytų rinką $[16,17]$. Daugumoje įmonių buvo naudojami pasenę ir neefektyvūs ịrenginiai bei technologijos, nemažai energijos dèl blogos pastatų šiluminès izoliacijos buvo švaistoma patalpų šildymui. Tačiau sparčiai augančios energijos išteklių kainos, perejjimas iš planinès ị rinkos ekonomiką ir kiti veiksniai lèmé dramatiškus pokyčius visose ūkio šakose. Šiuos pokyčius galima iliustruoti sparčiu energijos sąnaudų mažèjimu - $2000 \mathrm{~m}$. visoms šalies reikmèms suvartota 2,2 karto mažiau pirminès energijos išteklių nei $1990 \mathrm{~m}$. Nepaisant akivaizdžios pažangos mažinant bendrąsias šalies energijos sąnaudas ir didinant energijos vartojimo efektyvumą, ịvairiose studijose ir net oficialiuose dokumentuose [18] teigiama, kad Lietuvoje vienam BVP vienetui sukurti energijos suvartojama kelis kartus daugiau nei išsivysčiusiose šalyse ir tokiu būdu grindžiamas didelis energijos taupymo potencialas.

Energijos vartojimo efektyvumui apibūdinti tiek šalyje, tiek ir atskirose ūkio šakose dažniausiai naudojamas energijos intensyvumo rodiklis. Juo paprastai remiamasi, kai nèra galimybių apibūdinti energijos vartojimą lyginamaisiais techniniais ar fiziniais rodikliais. Energijos intensyvumas apibrèžiamas kaip pirminès energijos sąnaudų (įvertintų energijos vienetais) santykis su veiklos rodikliu (apskaičiuotu Nacionaline valiuta ar bendrąja valiuta pastoviomis kainomis [19]), kuris apibūdinamas šalyje sukurtu bendruoju vidaus produktu ar bendrąja pridètine verte. Nustatant energijos intensyvumo pokyčius bet kurioje šalyje ir ypač atliekant energijos intensyvumo rodiklių ìvairiose šalyse lyginamają̨ analizę, labai svarbu taikyti tuos pačius principus energijos sąnaudų ir BVP dinaminèms eilutems parengti.

Bendru atveju energijos vartojimo efektyvumą siekiama didinti tiek energijos tiekimo ir transformavimo, tiek ir galutinio vartojimo srityse. Ženklų pirminès energijos sąnaudų sumažèjimą absoliučiu dydžiu gali lemti esminiai pokyčiai elektros energetikos sektoriuje, pasikeitimai pirminès energijos balanse pagal energijos ištekliu vartojimo kryptis ir daug energijos taupančiu technologijų ìdiegimas ūkio šakose. Esant tai pačiai galutinių vartotojų struktūrai ir tokiems pat galutinès energijos poreikiams, pirminès energijos sąnaudų apimtis priklauso nuo:

- energijos transformavimo sektoriaus struktūros;

- energijos transformavimo įmonèse patiriamų nuostolių;

- energijos transportavimo ir paskirstymo nuostolių;

- energijos išteklių, suvartojamų neenergetinèms reikmèms, apimties;

- antrinès energijos išteklių (elektros energijos ir naftos produktų) importo ir eksporto bei kitų veiksnių.

Energijos taupymo potencialui įvertinti energijos tiekimo ir transformavimo grandyje gali būti taikomas galutinès energijos dalies bendrame pirminès energijos balanse rodiklis. Šiuo rodikliu galima apibrežti, kokia dalis visų energetinèms reikmėms šalyje sunaudotų pirminès energijos išteklių patiekiama galutiniams vartotojams. Kuo šis rodiklis didesnis, tuo mažiau energijos išteklių prarandama pakeliui iki vartotojų ir tuo mažiau energijos galima sutaupyti energijos tiekimo ir transformavimo grandyje. Beveik du dešimtmečius Lietuva buvo priskiriama prie tų šalių, kurių energetikos sektorius, eksportuodamas didelius kiekius elektros energijos ir naftos perdirbimo gamyklose pagamintų naftos produktų, pirminę energiją transformuoja patirdamas labai didelius nuostolius. Uždarius Ignalinos AE, šie nuostoliai gerokai sumažèjo ir galutinès energijos dalis 


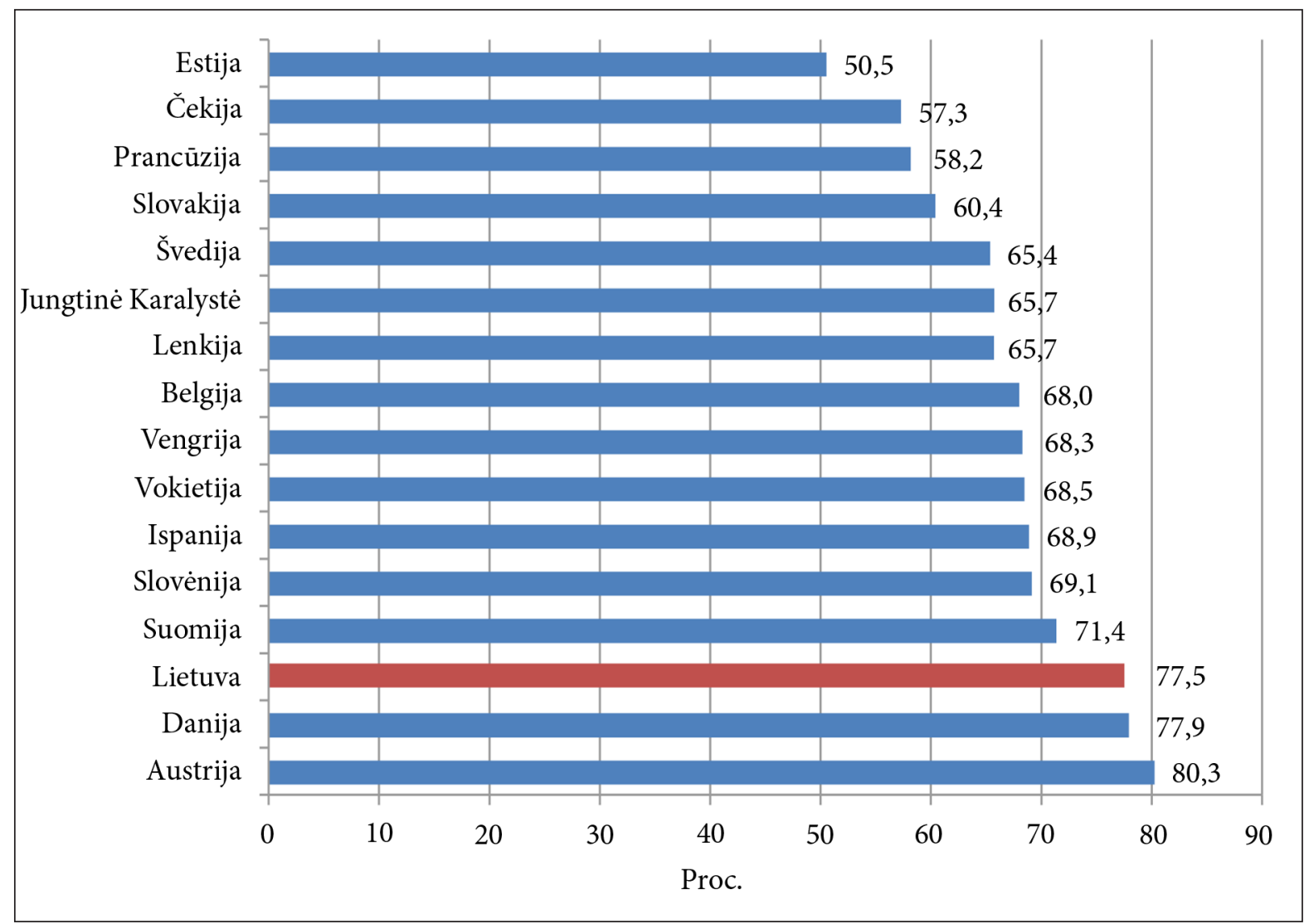

6 pav. Galutinès energijos dalis energetinėms reikmèms suvartotos pirminès energijos balanse $2011 \mathrm{~m}$.

nuo visų energetinėms reikmėms suvartojamų pirminès energijos išteklių padidèjo nuo 57,5 \% 2000 m. iki 78,6 \% 2012 m. Remiantis Tarptautinès energetikos agentūros statistikos leidiniuose pateiktais duomenimis [11, 12], nustatyta, kad pagal šị rodiklį Lietuva gali būti priskiriama prie pirmaujančių ES šalių (6 pav.).

Pokyčiai energijos transformavimo sektoriuje didele dalimi lèmé bendrą energijos vartojimo efektyvumo padidejjimą - $2012 \mathrm{~m}$. vienam sukurto BVP vienetui Lietuvoje sunaudota $64,4 \%$ mažiau pirminès energijos nei $2000 \mathrm{~m}$. Dèl energetinio saugumo ar remiantis kitais motyvais padidinus elektros energijos gamybos apimtis gamtines dujas naudojančiose šalies elektrinèse, ateityje būtų suvartojama daugiau pirminès energijos išteklių, atitinkamai padidetų energijos transformavimo nuostoliai ir energijos intensyvumas.

Nors pirminès energijos intensyvumas per dešimtmečius ženkliai sumažèjo, Lietuva vis dar priskiriama prie neefektyviai energiją vartojančių šalių, o teiginiai apie išlaidų energijos išteklių vartojimą Lietuvoje ir kitose naujosiose ES šalyse narèse paprastai grindžiami energijos intensyvumo rodikliais, kurie skelbiami ir periodiškai atnaujinami Eurostato duomenų bazeje. Remiantis 2014 m. gegužès mėn. skelbtais duomenimis [7], galima būtų teigti, kad Vidurio ir Rytų Europos šalyse BVP vienetui sukurti vis dar suvartojama 2-5 kartus (Bulgarijoje 4,7 karto, Estijoje 3,4 karto, Rumunijoje 2,6 karto, Čekijoje 2,5 karto, Slovakijoje 2,3 karto, Latvijoje 2,3 karto, Lenkijoje 2,1 karto, Lietuvoje 2 kartus, Vengrijoje 1,9 karto) daugiau energijos nei vidutiniškai ES-28 šalyse (7 pav.).

Tokius pat didelius pirminès energijos intensyvumo rodiklių skirtumus industrinèse ir besivystančiose šalyse demonstruoja duomenys, pateikti Tarptautinès energetikos agentūros leidiniuose [11, 12], kai visose šalyse sukurtas BVP iš nacionalinių valiutų perskaičiuotas ị bendrąją valiutą JAV doleriais $2005 \mathrm{~m}$. kainomis (8 pav.). Remiantis šiais rodikliais, paprastai daroma išvada apie labai dideli energijos taupymo potencialą Lietuvoje ir daugumoje kitų buvusio Rytų bloko šalių. Tačiau tokia išvada yra nekorektiš- 


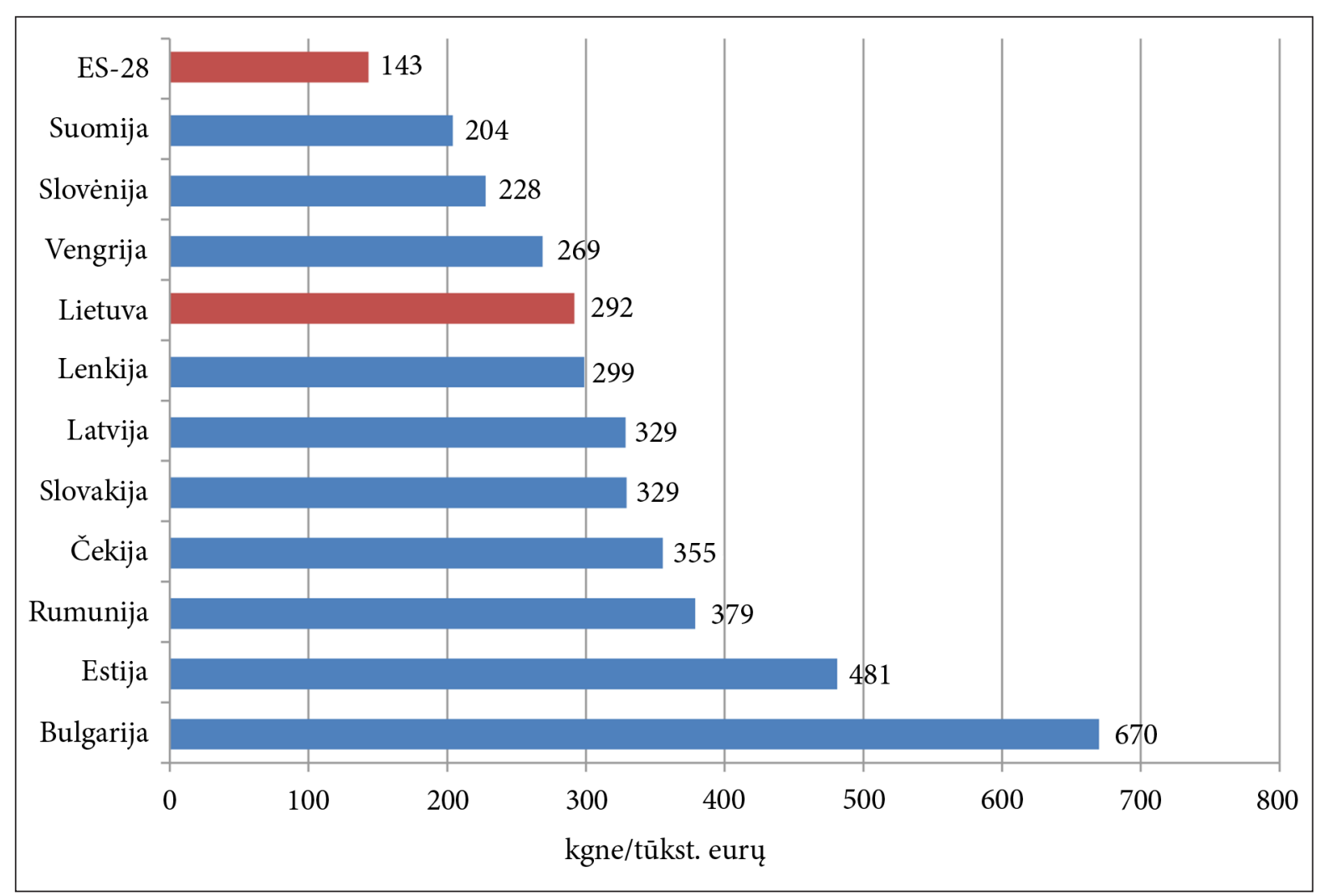

7 pav. Pirminès energijos intensyvumas 2012 m. taikant valiutų keitimo kurso metodą

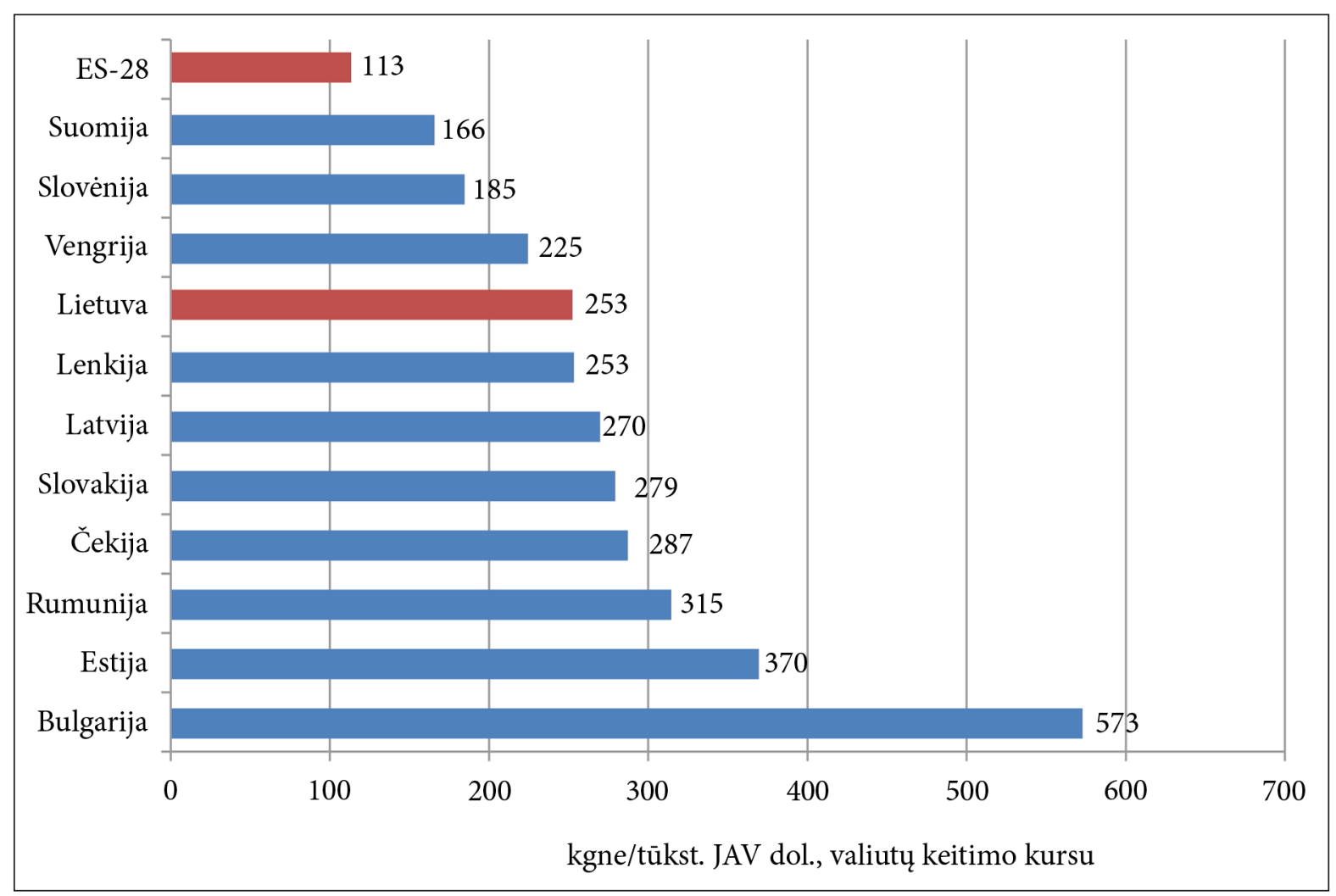

8 pav. Pirminès energijos intensyvumas $2011 \mathrm{~m}$. taikant valiutų keitimo kurso metodą 
ka, nes realios galimybės sumažinti lyginamąsias pirminès energijos sąnaudas yra gerokai mažesnès.

Labai dideli energijos intensyvumą besivystančiose šalyse iš esmès lemia tai, kad lyginamajai analizei šiose šalyse sukurtas BVP iš nacionalinių valiutų tiesiogiai perskaičiuojamas eurais arba JAV doleriais taikant valiutų keitimo kurso metodą. Šiuo atveju neatsižvelgiama nei ị perkamosios galios, nei i BVP apskaičiavimo atskirose šalyse skirtumus. Todèl didelį energijos intensyvumą iš esmès lemia ne tiek neefektyvus pirminès energijos išteklių vartojimas, kiek žemas BVP lygis besivystančiose šalyse, kai bendroji pridètinè pagaminamų prekių ir teikiamų paslaugų vertè perskaičiuojama tiesiogiai pagal nustatytus valiutų keitimo kurso rodiklius. Dèl kainų ir BVP vertinimo atskirose šalyse skirtumų tokių pačių prekių ir paslaugų bendroji pridètinè vertẻ besivystančiose šalyse yra kur kas mažesnè nei išsivysčiusiose šalyse. Todèl ir pirminès energijos sąnaudų, tenkančių BVP (perskaičiuoto ị bendrą tarptautinę valiutą pagal valiutų keitimo kursą) vienetui, rodiklis besivystančiose šalyse vis dar išlieka gerokai didesnis nepaisant to, kad energijos vartojimo efektyvumas šiose šalyse per praejjusi dešimtmetị gerokai padidèjo.

Siekiant korektiškai įvertinti lyginamajji energijos vartojimo efektyvumo didinimo potencialą, besivystančiose šalyse sukurtą BVP i̇ bendrąją valiutą būtina perskaičiuoti taikant perkamosios galios pariteto (PGP) rodiklius [20-22]. Šie rodikliai remiasi vienodo prekiu įsigijimo įvairiose šalyse galimybių vertinimu ir tiksliau atspindi kiekvienos šalies gyvenimo lygi. 9 pav. pateikti energijos intensyvumo rodikliai, nustatyti remiantis Tarptautinès energetikos agentūros statistikos leidiniuose pateiktais duomenimis, kai BVP vertinamas PGP metodu [11, 12]. Kaip matyti iš šių duomenų, Lietuvoje pirminès energijos intensyvumas $2011 \mathrm{~m}$., BVP vertinant JAV doleriais $2005 \mathrm{~m}$. kainomis, buvo tik 15,5\% didesnis nei vidutiniškai ES-28 šalyse. Kitose Vidurio ir Rytų Europos šalyse, išskyrus Estiją ir Bulgariją, pirminès energijos intensyvumas šiuo atveju yra mažesnis nei Suomijoje ir Belgijoje, artimas lygi-

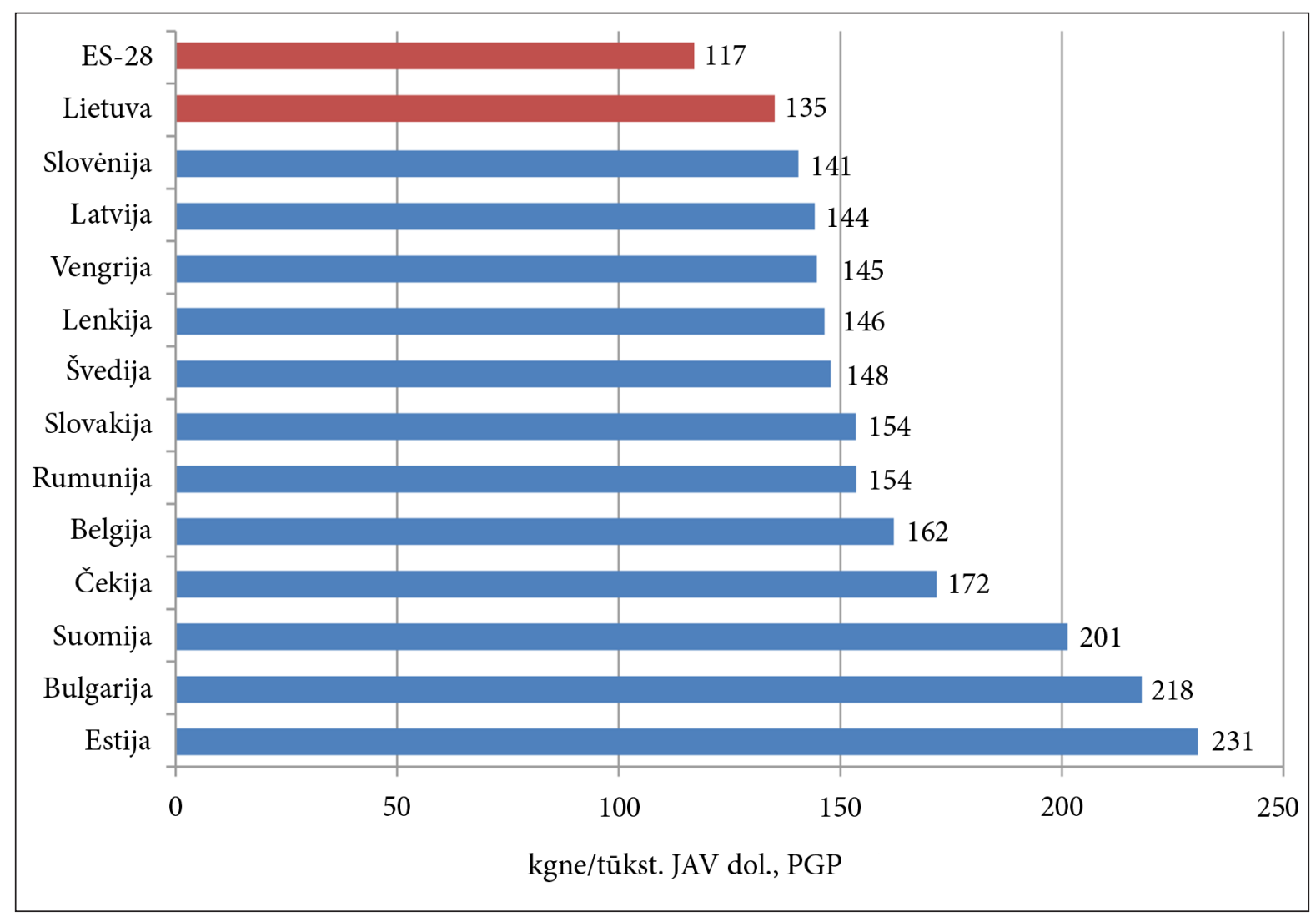

9 pav. Pirminès energijos intensyvumas $2011 \mathrm{~m}$. taikant perkamosios galios pariteto metodą 
namosioms energijos sąnaudoms BVP vienetui sukurti Švedijoje ir tik 20-40 \% didesnis nei ES28 vidurkis.

Tolesnis pirminès energijos intensyvumo mažinimas Lietuvoje labai reikšmingai priklauso nuo pastangų sumažinti galutinès energijos intensyvumą, t. y. nuo pažangos igyvendinant energijos vartojimo efektyvumą didinančias priemones šalies ūkio šakose. Galutinès energijos intensyvumo rodiklių, apibrèžiančių energijos sąnaudas bendrosios pridètinès vertès vienetui, ir veiksnių, turinčių didelę įtaką galutinio vartojimo efektyvumui didinti, analizè reikalauja išskirtinio dèmesio. Šiame straipsnyje esamos būklès apibūdinimas apsiriboja žemiau pateiktu lyginamujų galutinès energijos vartojimo rodiklių ES šalyse palyginimu.

\section{Energijos vartojimo lyginamieji rodikliai}

Energijos vartojimo ịvairiose šalyse analizei būtina aprèpti daug lyginamųjų rodiklių: galu- tinès energijos intensyvumo; elektros energijos intensyvumo; pirminès energijos sąnaudų, tenkančių vienam gyventojui; galutinès energijos sąnaudų, tenkančių vienam gyventojui; elektros energijos sąnaudų, tenkančių vienam gyventojui ir kt. Rengiant energetikos sektoriaus plètros studijas, tokių rodiklių lyginamoji analizè suteikia papildomų argumentų apibrèžiant realius šalies siekius, koreguojant įvairiais matematinio modeliavimo metodais nustatytas prognozes ir pan.

Apibūdinant lyginamąsias energijos vartojimo apimtis, energetikoje dažniausiai naudojami du rodikliai - pirminès energijos sąnaudos, tenkančios vienam gyventojui, ir elektros energijos sąnaudos, tenkančios vienam gyventojui. Gana retai analizuojami galutini energijos vartojimą apibrěžiantys rodikliai. Kaip matyti iš 3 lentelèje pateiktų duomenų, $2012 \mathrm{~m}$. Lietuvoje pirminès energijos vienam gyventojui buvo sunaudota 2,37 tne arba $41 \%$ mažiau nei vidutiniškai

3 lentelè. Lyginamieji energijos sąnaudu, tenkančių vienam gyventojui 2012 m., rodikliai

\begin{tabular}{|c|c|c|c|c|c|c|c|c|}
\hline & $\begin{array}{l}\text { Pirminė } \\
\text { energija }\end{array}$ & $\begin{array}{l}\text { Galutinè } \\
\text { energija }\end{array}$ & Pramonė & Transportas & $\begin{array}{c}\text { Namų } \\
\text { ükis }\end{array}$ & $\begin{array}{l}\text { Paslaugy } \\
\text { sektorius }\end{array}$ & $\begin{array}{l}\text { Galutinè } \\
\text { elektra }\end{array}$ & $\begin{array}{c}\text { Elektra } \\
\text { namų } \\
\text { ūkiuose }\end{array}$ \\
\hline & tne & tne & tne & tne & tne & tne & kWh & kWh \\
\hline Estija & 4,63 & 2,17 & 0,43 & 0,60 & 0,73 & 0,32 & 5275 & 1479 \\
\hline Latvija & 2,23 & 1,98 & 0,41 & 0,52 & 0,68 & 0,31 & 3366 & 873 \\
\hline Lietuva & 2,37 & 1,62 & 0,33 & 0,53 & 0,51 & 0,20 & 2985 & 884 \\
\hline Bulgarija & 2,50 & 1,26 & 0,35 & 0,42 & 0,33 & 0,14 & 3811 & 1483 \\
\hline Kroatija & 1,90 & 1,38 & 0,27 & 0,47 & 0,42 & 0,17 & 3595 & 1514 \\
\hline Čekija & 4,07 & 2,29 & 0,77 & 0,58 & 0,57 & 0,29 & 5389 & 1387 \\
\hline Lenkija & 2,54 & 1,65 & 0,39 & 0,45 & 0,51 & 0,21 & 3182 & 735 \\
\hline Slovakija & 3,09 & 1,91 & 0,80 & 0,43 & 0,38 & 0,27 & 4426 & 875 \\
\hline Slovėnija & 3,40 & 2,36 & 0,59 & 0,93 & 0,58 & 0,22 & 6099 & 1545 \\
\hline Rumunija & 1,76 & 1,13 & 0,34 & 0,27 & 0,40 & 0,09 & 2113 & 600 \\
\hline Vengrija & 2,37 & 1,49 & 0,26 & 0,40 & 0,52 & 0,28 & 3307 & 1070 \\
\hline ES-13 & 2,56 & 1,60 & 0,42 & 0,44 & 0,48 & 0,20 & 3436 & 941 \\
\hline Airija & 3,02 & 2,34 & 0,49 & 0,91 & 0,59 & 0,29 & 5267 & 1770 \\
\hline Austrija & 3,99 & 3,24 & 1,08 & 1,00 & 0,79 & 0,31 & 7472 & 2087 \\
\hline Danija & 3,24 & 2,53 & 0,41 & 0,82 & 0,79 & 0,35 & 5615 & 1787 \\
\hline $\begin{array}{l}\text { Jungtinė } \\
\text { Karalystė }\end{array}$ & 3,18 & 2,10 & 0,41 & 0,79 & 0,62 & 0,25 & 4985 & 1800 \\
\hline Prancūzija & 3,95 & 2,30 & 0,45 & 0,77 & 0,64 & 0,34 & 6633 & 2418 \\
\hline Suomija & 6,30 & 4,67 & 2,02 & 0,89 & 1,00 & 0,36 & 14913 & 4107 \\
\hline Švedija & 5,23 & 3,40 & 1,23 & 0,87 & 0,78 & 0,47 & 13369 & 4084 \\
\hline Vokietija & 3,97 & 2,65 & 0,76 & 0,76 & 0,72 & 0,41 & 6537 & 1703 \\
\hline ES-15 & 3,54 & 2,34 & 0,60 & 0,76 & 0,60 & 0,32 & 6095 & 1825 \\
\hline ES-28 & 3,33 & 2,19 & 0,56 & 0,70 & 0,57 & 0,29 & 5539 & 1640 \\
\hline
\end{tabular}


tenka vienam gyventojui ES-28 šalyse ir apie $10 \%$ mažiau nei vidutiniškai naujosiose ES šalyse narèse. Galutinès energijos lyginamosios sąnaudos vienam gyventojui Lietuvoje yra 35 \% mažesnès nei ES-28 vidurkis, o atskirose ūkio šakose skirtumai dar didesni - šalies pramoneje $2012 \mathrm{~m}$. suvartota $67 \%$, paslaugų sektoriuje $-44 \%$, transporte $-32 \%$, namų ūkiuose - $11 \%$ mažiau nei vidutiniškai ES. Dar daugiau skiriasi vienam gyventojui tenkančios galutinès elektros energijos, kuri tiesiogiai suvartojama ūkio šakose, lyginamieji rodikliai. Lietuvoje elektros vienas gyventojas 2012 m. suvartojo 1,8 karto mažiau nei Estijoje, 1,9 karto mažiau nei vidutiniškai ES-28 šalyse, 2,2 karto mažiau nei Vokietijoje, 5 kartus mažiau nei Suomijoje.

Namų ūkio sektoriuje $2012 \mathrm{~m}$. Lietuvoje vienas gyventojas suvartojo $884 \mathrm{kWh}$, ES-28 šalyse vidutiniškai $1640 \mathrm{kWh}$, ES-13 šalyse $941 \mathrm{kWh}$. Visuotinai pripažịstama, kad didesnès lyginamosios elektros energijos sąnaudos apibūdina aukštesnị techninị šalies ekonomikos išsivystymo lygi, geresnes galimybes tolesniam ekonomikos augimui, didesnį komfortą.

İvairių energijos vartojimą apibūdinančių rodikliu lyginamoji analize patvirtina, kad realios galimybès ženkliai padidinti energijos vartojimo efektyvumą Lietuvoje yra palyginti ribotos. Tačiau siekis didinti energijos vartojimo efektyvumą išlieka vienu svarbiausių Lietuvos strateginių tikslų. Šis siekis gali būti igyvendinamas vykdant struktūrinius pokyčius šalies ekonomikoje, diegiant naujas technologijas energijos transformavimo ir galutinio vartojimo srityse. Neabejotinai didžiausią energijos išteklių taupymo efektą galima pasiekti atnaujinant gyvenamuosius ir visuomeninius pastatus bei modernizuojant jų vidaus šildymo sistemas.

\section{IŠVADOS}

1. Galutinès energijos išteklių vartojimo kaitos 2000-2012 m. laikotarpiu analizė patvirtino bendrą Baltijos šalims energijos poreikių augimo tendenciją. Nežiūrint nukrypimų nuo bendros tendencijos, kuriems didelès itakos turèjo BVP augimo tempų skirtumai, skirtingas ekonomikos nuosmukio gylis, nevienoda galutinių vartotojų reakcija i pokyčius rinkoje, bendras galutinès energijos sąnaudų augimo indeksas 2000-2012 m. laikotarpiu skiriasi nedaug - Estijoje buvo lygus $22,1 \%$, Latvijoje - 23,9 \%, Lietuvoje - 28,4\%. Galutinès energijos ir BVP elastingumo koeficientai skiriasi dar mažiau - esant prielaidai, kad visų kitų veiksnių itaka tokia pat, BVP padidejus $1 \%$, Estijoje galutinès energijos sąnaudos augo $0,42 \%$, Latvijoje $-0,46 \%$, Lietuvoje $-0,47 \%$.

2. Pokyčiai energijos transformavimo sektoriuje didele dalimi lemè bendrą energijos vartojimo efektyvumo padidejjimą - $2012 \mathrm{~m}$. vienam sukurto BVP vienetui Lietuvoje sunaudota 64,4 \% mažiau pirminès energijos nei $2000 \mathrm{~m}$. Remiantis Tarptautinès energetikos agentūros paskelbtais statistiniais duomenimis, Lietuvoje pirminès energijos intensyvumas $2011 \mathrm{~m}$., šalyje sukurtą BVP vertinant JAV doleriais $2005 \mathrm{~m}$. kainomis ir taikant PGP metodą, buvo tik 15,5\% didesnis nei vidutiniškai ES-28 šalyse.

3. Lietuva ir kitos Baltijos šalys turi spartaus ekonomikos augimo viziją vidutinès trukmès ir ilgalaikejje perspektyvoje. Todèl ekonomikos augimas gali lemti ne tik galutinès energijos, bet ir nuosaikų pirminès energijos poreikių augimą. Energijos poreikių augimą galima sumažinti:

- atnaujinant daugiabučius gyvenamuosius namus ir visuomeninius pastatus, prijungtus prie centralizuoto šilumos tiekimo sistemų;

- atnaujinant decentralizuoto sektoriaus pastatus ir modernizuojant juose esančius kurą deginančius įrenginius bei vidaus šildymo sistemas;

- igyvendinant kitas energijos vartojimo efektyvumą didinančias priemones visose ūkio šakose.

Gauta 20140430 Priimta 20140520

\section{Literatūra}

1. Miškinis V., Galinis A., Vilemas J. Tyrimai energetikos sistemų optimizavimo srityje ir Nacionalinès energetikos strategijos evoliucija. Lietuvos mokslas. $61 \mathrm{kn}$., Lietuvos energetikos institutas - 50. Vilnius, 2006. P. 70-106.

2. Miškinis V., Galinis A. Lietuvos nacionalinès energetikos strategijos gairès. Energetika. 2006. Nr. 3. P. 24-32.

3. Miškinis V., Galinis A., Konstantinavičiūtė I. Challenges and options for development of the 
Lithuanian energy sector. International Journal of Global Energy Issues. 2010. Vol. 34. Nos. 1-4. P. 91-111.

4. Energy Statistics Manual. International Energy Agency, 2004.

5. Miškinis V. Lietuvos energetinis balansas: metodologija, poreikių dinamika, struktūriniai pokyčiai. Energetika. 1996. Nr. 2. P. 48-57.

6. Kuro ir energijos balansas 2012. Vilnius: Statistikos departamentas prie Lietuvos Respublikos Vyriausybès, 2013.

7. Eurostato duomeny baze. Prieiga per internetą: http://epp.eurostat.ec.europa.eu/portal/ page/portal/statistics/search_database [žiūrèta 2014 m. gegužès 27 d.].

8. Energy Balances of Non-OECD Countries 20012002. International Energy Agency, 2004.

9. Energy Balances of OECD Countries 2001-2002. International Energy Agency, 2004.

10. Latvijas Statistika. Annual Statistical Data. Energy Balance. http://www.csb.gov.lv/en/dati/statistics-database-30501.html

11. Energy Balances of OECD Countries. Edition 2013. International Energy Agency, 2013.

12. Energy Balances of Non-OECD Countries. Edition 2013. International Energy Agency, 2013.

13. Lietuvos BVP ir energijos balansas, tūkst. tony naftos ekvivalentu. Prieiga per internetą: http:// db1.stat.gov.lt/statbank/default.asp? $w=2021$ [žiūrèta $2014 \mathrm{~m}$. kovo mèn.].

14. Eesti Stasistics. Energy Consumption and Production. http://pub.stat.ee/px-web.2001/I_Databas/ Economy/07Energy/02Energy_consumption_ and_production/01Annual_statistics/01Annual_statistics.asp

15. 2012 m. spalio 25 d. Europos Parlamento ir Tarybos direktyva 2012/27/ES del energijos vartojimo efektyvumo, kuria iš dalies keičiamos direktyvos 2009/125/EB ir 2010/30/ES bei kuria panaikinamos direktyvos 2004/8/EB ir 2006/32/ $E B$. Prieiga per internetą: http://eur-lex.europa.eu/LexUriServ/LexUriServ.do?uri=OJ:L:2012:315:0001:0056:LT:PDF

16. Valentukevičius V., Miškinis V. Energy conservation policy in Lithuania: experiences and problems. International Journal of Global Energy Issues. 2001. Vol. 16. Nos. 1-3. P. 82-100.
17. Miskinis V. Energy demand forecasting in economies in transition. Energy Studies Review. 2002. Vol. 10. No. 2. P. 100-120.

18. Nacionalinè energetinès nepriklausomybès strategija, patvirtinta Lietuvos Respublikos Seimo 2012 m. birželio 26 d. nutarimu Nr. XI-2133. (Žin., 2012, Nr. 80-4149).

19. Grandininio susiejimo metodo taikymo bendrojo vidaus produkto apimties kitimo tempams skaičiuoti metodika. Prieiga per internetą: http://osp. stat.gov.lt/documents/10180/648955/Metodika_ 2006DI132.pdf/07d61b48-25a8-4bf0-ba58-c3fa$785 \mathrm{af} 98 \mathrm{f}$

20. Miskinis V., Vilemas J., Konstantinaviciute I. Analysis of energy consumption and energy intensity indicators in Central and Eastern European Countries. Energy Studies Review. 2006. Vol. 14. No. 2. P. 171-188.

21. Juknys R., Miškinis V., Dagiliūtè R. New eastern EU member states: decoupling of environmental impact from fast economy growth. Aplinkos tyrimai, inžinerija ir vadyba. 2005. Nr. 4. P. 6876.

22. Konstantinavičiūte I., Miškinis V., Navickas A. Energijos poreikiu kaita ir ju prognozavimo metodai. Mokomoji knyga. Kaunas: Technologija, 2010. 146 p.

Vaclovas Miškinis, Arvydas Galinis, Inga Konstantinavičiūtė, Vidas Lekavičius

\section{ENERGY CONSUMPTION TRENDS IN LITHUANIA AND EU COUNTRIES}

\section{Summary}

Analysis of the Lithuanian energy sector development over medium and long-term periods and preparation of strategic documents is a complex problem. Comprehensive analysis of energy consumption trends and application of appropriate energy planning tools is required. Forecast of final energy demand should be prepared taking into consideration that favourable preconditions for economic development of the national economy are required. The aim of this paper is to set out findings from the analysis of primary and final energy consumption in Lithuania over the period 2000-2012, to discuss the methodology of such analysis, to assess relationships between energy consump- 
tion and economic activities, as well as to perform a comparative analysis of energy intensity and indicators of energy consumption in the Baltic States and EU countries.

Key words: primary energy, final energy, energy intensity, energy balance

Вацловас Мишкинис, Арвидас Галинис,

Инга Константинавичюте, Видас Лекавичюс

ТЕНДЕНЦИИ ПОТРЕБЛЕНИЯ ЭНЕРГИИ В ЛИТВЕ И СТРАНАХ ЕС

Резюме

Разработка направлений перспективного развития энергетики Литвы, а также стратегических документов является предметом комплексных энергетических исследований. Направления развития энергетики должны быть основаны на всестороннем анализе тенденций энергопотребления с применением современных методов перспективного планирования. При прогнозировании потребности в конечной энергии необходимо учесть необходимость создания благоприятных условий для развития экономики страны. Цель настоящей статьи - обобщение тенденций потребления первичной и конечной энергии в Литве в течение 20002012 г. г., обсуждение принципов такого анализа, выявление взаимосвязей потребления энергии и роста экономики, а также сравнительный анализ энергоемкости и удельных показателей энергопотребления в странах Балтии и Европейского Союза.

Ключевые слова: первичная энергия, конечная энергия, энергоемкость, энергетический баланс 